\title{
RISK FACTORS OF BODY MASS INDEX (BMI), AGE OF MENARCHE, PARITY AND HORMONAL CONTRACEPTION OF GENU OSTEOARTHRITIS IN FEMALE PATIENTS
}

\author{
Alisiya Alisiya ${ }^{1 *}$, Sulistiawati Sulistiawati ${ }^{2}$, Patricia Maria Kurniawati ${ }^{3}$, RR. Indrayuni Lukitra Wardhani ${ }^{3}$ \\ ${ }^{1}$ Faculty of Medicine, Universitas Airlangga, Surabaya, Indonesia \\ ${ }^{2}$ Department of Public Health Science-Preventive Medicine, Faculty of Medicine, Universitas Airlangga/Dr. \\ Soetomo General Academic Hospital \\ ${ }^{3}$ Department of Physical Medicine and Rehabilitation, Faculty of Medicine, Universitas Airlangga/Dr. Soetomo \\ General Academic Hospital
}

\section{ABSTRACT}

Osteoarthritis $(O A)$ is a degenerative disease related to joint cartilage and commonly occurs in the knee joint. The 2013 National Survey recorded the prevalence of joint diseases in East Java was 26.9\%. OA affected more women than men due to the estrogen and caused disabilities in many women. This study aimed to find the relationship between Body Mass Index (BMI), age of menarche, parity, and the use of hormonal contraceptives against OA in genu at Universitas Airlangga Hospital, Surabaya. This was an analytic observational study with a case control approach. Data collection was carried out through a short interview using a questionnaire. Sample size was calculated using formula and found that the study required 42 patients with $O A$ in case group and 42 patients without OA in control group. The case group was dominated by patients with 56-60 years-old age (62.1\%), BMI 23-24.9 kg/m² (58.7\%), menarche age $12-13$ years $(53.6 \%)$, multiparous (52.6\%), having contraception pill usage history (62.3\%) particularly using combination pills (60.5\%) with mean duration of use >1 year $(56.8 \%)$. There was a relationship between BMI and type of hormonal contraceptive used against genu OA in female patients at Universitas Airlangga Hospital Surabaya.

Keywords: Osteoarthritis (OA); women; estrogen; body mass index; menarche; parity; contraceptive

\section{ABSTRAK}

Osteoartritis $(O A)$ adalah penyakit degeneratif yang berhubungan dengan tulang rawan sendi dan umumnya terjadi pada sendi lutut. Survei Nasional tahun 2013 mencatat prevalensi penyakit sendi di Jawa Timur sebesar 26,9\%. OA lebih banyak mempengaruhi wanita daripada pria dikarenakan estrogen yang terkandung di dalamnya. OA juga dapat menyebabkan kecacatan pada banyak wanita. Penelitian ini bertujuan untuk mengetahui hubungan antara Indeks Massa Tubuh (IMT), umur menarche, paritas, dan penggunaan kontrasepsi hormonal terhadap OA genu di RS Universitas Airlangga Surabaya. Jenis penelitian ini adalah observasional analitik dengan pendekatan case-control. Pengumpulan data dilakukan melalui wawancara singkat melalui kuesioner. Besar sampel dihitung menggunakan rumus dan ditemukan bahwa penelitian ini membutuhkan 42 pasien OA pada kelompok kasus dan 42 pasien tanpa OA pada kelompok kontrol. Kelompok kasus didominasi oleh pasien dengan usia 56-60 tahun (62,1\%), IMT 23-24,9 kg/m2 (58,7\%), usia menarche 12-13 tahun (53,6\%), multipara (52,6\%), riwayat penggunaan pil kontrasepsi (62,3\%); terutama yang menggunakan pil kombinasi $(60,5 \%)$ dengan rata-rata lama pemakaian lebih dar satu tahun (56,8\%). Penelitian ini dapat memberikan kesimpulan bahwa terdapat hubungan antara IMT dan jenis kontrasepsi hormonal yang digunakan terhadap OA genu pada pasien wanita di RS Universitas Airlangga Surabaya.

Kata kunci: penggunaan antibiotik kualitatif; bijaksana; infeksi

Correspondence: Sulistiawati, Department of Public Health Science-Preventive Medicine, Faculty of Medicine, Universitas Airlangga/Dr. Soetomo General Academic Hospital, Surabaya, Indonesia. Email: sulistiawati@fk.unair.ac.id

pISSN:2355-8393 • eISSN: 2599-056x • doi: 10.20473/fmi.v57i2.23029

- Fol Med Indones. 2021;57:104-110 • Received 04 Nov 2020 • Accepted 14 Jan 2020

- Open access under CC-BY-NC-SA license • Available at https://e-journal.unair.ac.id/FMI/ 


\section{INTRODUCTION}

Osteoarthritis $(\mathrm{OA})$ is a degenerative disease related to joint cartilage and generally occurs in the knee joint (Zhang \& Jordan 2010). In Koentjoro's study (2010), the prevalence of knee OA in Indonesia is quite high, reaching $15.5 \%$ in men, and $12.7 \%$ in women from the total population of Indonesia, amounting to 255 million people. In East Java, the prevalence of joint disease is 26.9\% (Ministry of Health 2013). Osteoarthritis is often associated with an aging process that is inevitable, but this is not entirely true, experts argue that $\mathrm{OA}$ is a homeostatic disturbance of cartilage metabolism with cartilage proteoglycan structure damage which cause is not clear.

There are approximately 151.400 .000 people worldwide suffer from osteoarthritis. In addition, osteoarthritis is the fifth disease that causes Years of Life Disability in women in developed countries. In developing countries, osteoarthritis ranked eighth for the cause of Years of Disability (Sheikh \& Khanam 2013).

Osteoarthritis (OA) affects women more often than men. This is related to the menopause process. The menopause process is related to the levels of the estrogen hormone, where one of its functions is to maintain bone density (Salim 2016). The body shape of women which is wider at the hips compared to men whose body shape tend to be straight is one of the reasons women are more at risk of developing osteoarthritis. Overtime, fat will increase in the hips and stomach as women get older. This will put more workload on the knee to support body mass (Johnsen et al 2017).

This study was to investigate the relationship between Body Mass Index (BMI), age of menarche, history of parity and use of hormonal contraceptives against osteoarthritis genu. These risk factors were chosen to be analyzed in this study, because they were one of the suspected triggers for osteoarthritis genu and one of the modifiable risk factors (Hellevik et al 2017).

\section{MATERIALS AND METHODS}

This study was an analytic observational study with case control approach. The method used in this study was a short interview using questionnaire as an interview guide, where we interviewed Osteoarthritis patients (case group) and non-Osteoarthritis patients (control group) with questionnaire guide as a data collection tool. The population was the entirety of object to be studied. The population of this study were all 40-60 years women at the Rehabilitation Clinic and Internal Medicine Outpatient Clinic at Universitas Airlangga Hospital, Surabaya who met the inclusion and exclusion criteria. The case group was a female patient aged 40-60 years at the Rehabilitation Clinic who was diagnosed with Osteoarthritis by a doctor at the Universitas Airlangga Hospital, Surabaya. Meanwhile, the control group was a female patient aged 40-60 years at the Internal Medicine Outpatient Clinic who was not diagnosed with Osteoarthritis by a doctor at the University Hospital. Airlangga, Surabaya.

The inclusion criteria included female patients aged 4060 years at the Rehabilitation Clinic and Internal Medicine Outpatient Clinic at Universitas Airlangga Hospital, Surabaya, being diagnosed with osteoarthritis by a doctor, and not being diagnosed with osteoarthritis by a doctor. The exclusion criteria were incomplete medical record data and being unable to interview. The independent variables (risk factor variables) were body mass index (BMI), age of menarche, parity, and use of hormonal contraceptives. The dependent variable (effect variable) was osteoarthritis genu. The data were analyzed using univariate and bivariate analysis. Bivariate analysis was performed to determine the relationship between each risk factor (independent variable) and the occurrence of osteoarthritis genu in women (dependent variable) by using the chi-square test.

\section{RESULTS}

The data were taken when the patient was going through examination at Universitas Airlangga Hospital on October 2019 to March 2020. The data were obtained from the questionnaire result distributed to nonosteoarthritis female patients at the Internal Medicine Outpatient Clinic and to osteoarthritis female patients at the Medical Rehabilitation Clinic amounting to 84 patients. 
Table 1. Osteoarthritis female patients' characteristics

\begin{tabular}{|c|c|c|c|}
\hline \multirow[b]{2}{*}{ Variable } & \multicolumn{2}{|c|}{ Patient } & \multirow[t]{2}{*}{ Total } \\
\hline & $\begin{array}{c}\text { Medical } \\
\text { Rehabilitation Clinic } \\
\text { (Osteoarthritis) }\end{array}$ & $\begin{array}{c}\text { Internal Medicine } \\
\text { Outpatient Clinic } \\
\text { (Non- } \\
\text { Osteoarthritis) }\end{array}$ & \\
\hline \multicolumn{4}{|l|}{$\overline{\text { Age }}$} \\
\hline 40-45 у. о. & $\begin{array}{c}3 \\
25,0 \%\end{array}$ & $\begin{array}{c}9 \\
75,0 \%\end{array}$ & $\begin{array}{c}12 \\
100,0 \%\end{array}$ \\
\hline 46-50 у. о. & $\begin{array}{c}11 \\
61,1 \%\end{array}$ & $\begin{array}{c}7 \\
38,9 \%\end{array}$ & $\begin{array}{c}18 \\
100,0 \%\end{array}$ \\
\hline 51-55 у. о. & $\begin{array}{c}10 \\
40,0 \% \\
18\end{array}$ & $\begin{array}{c}15 \\
60,0 \%\end{array}$ & $\begin{array}{c}25 \\
100,0 \%\end{array}$ \\
\hline 56-60 у. о. & $\begin{array}{c}18 \\
62,1 \% \\
\end{array}$ & $37,9 \%$ & $\begin{array}{c}29 \\
100,0 \%\end{array}$ \\
\hline Total & $\begin{array}{c}42 \\
50,0 \% \\
\end{array}$ & $\begin{array}{c}42 \\
50,0 \% \\
\end{array}$ & $\begin{array}{c}84 \\
100,0 \% \\
\end{array}$ \\
\hline \multicolumn{4}{|l|}{ Menarche Age } \\
\hline 10-11 у. о. & $\begin{array}{c}14 \\
45,2 \%\end{array}$ & $\begin{array}{c}17 \\
54,8 \%\end{array}$ & $\begin{array}{c}31 \\
100,0 \%\end{array}$ \\
\hline 12-13 у. о. & $\begin{array}{c}21 \\
53,6 \%\end{array}$ & $\begin{array}{c}18 \\
46,2 \%\end{array}$ & $\begin{array}{c}39 \\
100,0 \%\end{array}$ \\
\hline Others & $\begin{array}{c}7 \\
50,0 \%\end{array}$ & $\begin{array}{c}7 \\
50,0 \%\end{array}$ & $\begin{array}{c}14 \\
100,0 \%\end{array}$ \\
\hline Total & $\begin{array}{c}42 \\
50,0 \% \\
\end{array}$ & $\begin{array}{c}42 \\
50,0 \% \\
\end{array}$ & $\begin{array}{c}84 \\
100,0 \% \\
\end{array}$ \\
\hline \multicolumn{4}{|l|}{ Parity } \\
\hline 10-11 у. о. & $\begin{array}{c}14 \\
45,2 \%\end{array}$ & $\begin{array}{c}17 \\
54,8 \%\end{array}$ & $\begin{array}{c}31 \\
100,0 \%\end{array}$ \\
\hline 12-13 у. о. & $\begin{array}{c}21 \\
53,6 \%\end{array}$ & $\begin{array}{c}18 \\
46,2 \%\end{array}$ & $\begin{array}{c}39 \\
100,0 \%\end{array}$ \\
\hline Others & $\begin{array}{c}7 \\
50,0 \%\end{array}$ & $\begin{array}{c}7 \\
50,0 \%\end{array}$ & $\begin{array}{c}14 \\
100,0 \%\end{array}$ \\
\hline Total & $\begin{array}{c}42 \\
50,0 \% \\
\end{array}$ & $\begin{array}{c}42 \\
50,0 \% \\
\end{array}$ & $\begin{array}{c}84 \\
100,0 \% \\
\end{array}$ \\
\hline \multicolumn{4}{|l|}{ Contraceptive } \\
\hline Pill & $\begin{array}{c}33 \\
62,3 \%\end{array}$ & $\begin{array}{c}20 \\
37,7 \%\end{array}$ & $\begin{array}{c}53 \\
100,0 \%\end{array}$ \\
\hline Injection & $\begin{array}{c}9 \\
34,6 \%\end{array}$ & $\begin{array}{c}17 \\
65,4 \%\end{array}$ & $\begin{array}{c}26 \\
100,0 \%\end{array}$ \\
\hline Implant & $\begin{array}{c}0 \\
0,0 \%\end{array}$ & $\begin{array}{c}5 \\
100,0 \%\end{array}$ & $\begin{array}{c}5 \\
100,0 \%\end{array}$ \\
\hline Total & $\begin{array}{c}42 \\
50,0 \% \\
\end{array}$ & $\begin{array}{c}42 \\
50,0 \% \\
\end{array}$ & $\begin{array}{c}84 \\
100,0 \% \\
\end{array}$ \\
\hline \multicolumn{4}{|l|}{ Pill Type } \\
\hline Progesterone Pill & $\begin{array}{c}23 \\
60,5 \% \\
10 \\
66,7 \%\end{array}$ & $\begin{array}{c}15 \\
39,5 \% \\
5 \\
33,3 \%\end{array}$ & $\begin{array}{c}38 \\
100,0 \% \\
15 \\
100,0 \%\end{array}$ \\
\hline Other Contraceptive & $\begin{array}{c}9 \\
29,0 \% \\
\end{array}$ & $\begin{array}{c}22 \\
71,0 \% \\
\end{array}$ & $\begin{array}{c}31 \\
100,0 \% \\
\end{array}$ \\
\hline Total & $\begin{array}{c}42 \\
50,0 \% \\
\end{array}$ & $\begin{array}{c}42 \\
50,0 \% \\
\end{array}$ & $\begin{array}{c}84 \\
100,0 \% \\
\end{array}$ \\
\hline \multicolumn{4}{|l|}{ Usage Duration } \\
\hline$<1 \mathrm{y} .0$. & $\begin{array}{c}15 \\
45,5 \%\end{array}$ & $\begin{array}{c}18 \\
54,5 \%\end{array}$ & $\begin{array}{c}33 \\
100,0 \%\end{array}$ \\
\hline
\end{tabular}




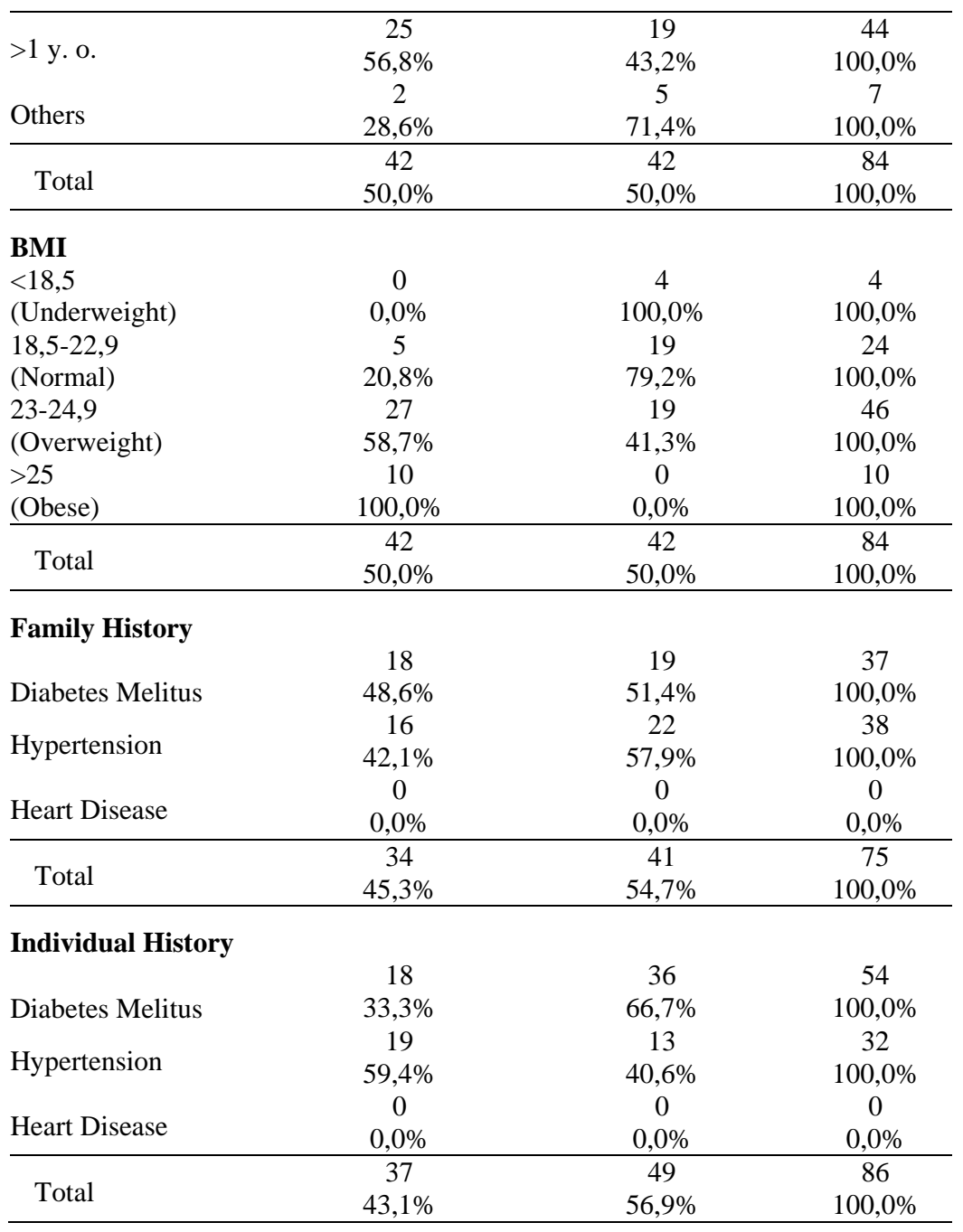

Table 1 showed the characteristics of female osteoarthritis patients. The majority of patients were in the 56-60 years age group. The highest proportion of osteoarthritis patient was in the 56-60 years age group at $62.1 \%$. The highest proportion of non-osteoarthritis patient was in the $40-45$ years age group at $75 \%$. Based on BMI, the majority of patients were in the overweight BMI group. The highest proportion of Osteoarthritis patient was in the obese group at $100 \%$. The highest proportion of Non-osteoarthritis patient was in the underweight group at $100 \%$. The majority of patients were in the 12-13 years menarche age group. The highest proportion of osteoarthritis patients was in the 12-13 years menarche age group at $53.6 \%$. The highest proportion of non-osteoarthritis was in the 10-11 years' menarche age group at $54.8 \%$.

Patient characteristics based on parity indicated that the majority of patients were multiparous. The highest proportion of osteoarthritis patient was in the multiparous group at $52.6 \%$. The highest proportion of non-osteoarthritis was in the grandemultiparous group at $80 \%$. Based on the use of hormonal contraceptive, the majority of patients used the contraceptive pill. The highest proportion of osteoarthritis patients was in the contraceptive pill user group as many as $62.3 \%$. The highest proportion of non-osteoarthritis was in the injection user group at $65.4 \%$. The majority of patients used combination pills. The highest proportion of osteoarthritis patient was in the progesterone pill group at $66.7 \%$. The highest proportion of non-osteoarthritis was in another contraceptive pill group at $71.0 \%$. Based on the duration of contraceptive usage, the majority of patients used contraceptive $>1$ year. The highest proportion of Osteoarthritis patient was in the > 1-year contraceptive user group at 56.8\%. The highest proportion of non-Osteoarthritis was in another user group at $71.4 \%$. 
Table 2. Research analysis on osteoarthritis and non-osteoarthritis group

\begin{tabular}{llllll}
\hline Category & \multicolumn{2}{l}{ Osteoarthritis } & Non-Osteoarthritis & $\begin{array}{l}\boldsymbol{P} \\
\text { value }\end{array}$ \\
& $\mathbf{n}$ & $\boldsymbol{\%}$ & $\mathbf{N}$ & $\boldsymbol{\%}$ & \\
\hline BMI & & & & & \\
$<18,5 \mathrm{~kg} / \mathrm{m}^{2}$ & 0 & 0,0 & 4 & 9,5 & \\
$18,5-22,9 \mathrm{~kg} / \mathrm{m}^{2}$ & 5 & 11,9 & 19 & 45,2 & 0,0001 \\
$23-24,9 \mathrm{~kg} / \mathrm{m}^{2}$ & 27 & 64,3 & 19 & 45,2 & \\
$>25 \mathrm{~kg} / \mathrm{m}^{2}$ & 10 & 23,8 & 0 & 0,0 & \\
\hline Total & 42 & 100,0 & 42 & 100,0 & \\
\hline Contraceptive & & & & & \\
Type & 33 & 78,6 & 20 & 47,6 & \\
Pill & 9 & 21,4 & 17 & 40,5 & \\
Injection & 0 & 0,0 & 5 & 11,9 & \\
Implant & 42 & 100,0 & 42 & 100,0 & \\
\hline Total & & & & & \\
\hline
\end{tabular}

In Table 2, BMI of 23-24.9 (overweight) had more amount than the other categories in the case and control groups. The $P$ value was $0.0001<\alpha(0.05)$, which indicated that there was a relationship between BMI and osteoarthritis. The data obtained based on the type of contraceptive showed pills have more amount compared to other categories in the case and control groups. The $P$ value was $0.004<\alpha(0.05)$, which indicated that there was a relationship between the type of contraceptive and osteoarthritis.

\section{DISCUSSION}

The total number of patients in this study were 84 patients who were taken using the questionnaire method through interviews in 2019 at the Universitas Airlangga Hospital Surabaya which were divided into two groups, namely the case group (osteoarthritis) as many as 42 patients and the control group (non-osteoarthritis) as many as 42 patients. Each group was analyzed for age, body mass index (BMI), age of menarche, parity and previous history of hormonal contraceptive use. The highest proportion of age in the case or osteoarthritis (OA) group was in the age range of 56-60 years, as many as 18 patients or $62.1 \%$. In the control or nonosteoarthritis (OA) group, the highest proportion of age was in the 51-55 years age range, as many as 15 patients or $60 \%$. This is in accordance with the alleged theory that the prevalence of knee OA increases with age and occurs in many women. A conducted research at the Medical Rehabilitation Installation of RSUP Prof. Dr. R. D. Kandou Manado on January - June 2017 also showed that knee OA patients in women were greater than men, amounting to $70.4 \%$ (Soeryadi et al 2017).
The occurrence of OA is thought to be multifactorial, including anatomical and hormonal differences, especially estrogen hormone which has protective factors against cartilage. In addition, the older a person is, the older the cells and the extracellular matrix. Basically, OA occurs due to an imbalance of anabolic and catabolic processes in cartilage joints, and the state of cell aging contributes to this. Aging chondrocyte cells have a poor response against growth factor stimulation, so that homeostasis of the articular cartilage is disrupted. In addition, the condition of aging chondrocyte cells also increases their susceptibility to cell death, so that cartilage cannot form properly (Anderson \& Loeser 2010). The highest percentage of BMI of female patients in the case group or Osteoarthritis (OA) patients was in the BMI range of 23-24.9 (overweight), which was 27 patients or $58.7 \%$. In the control group or non-osteoarthritis (OA), the highest percentage was in the BMI range between 18.522.9 (normal) and 23-24.9 (overweight) which was 19 patients or $79.2 \%$ and $41.3 \%$. This is in accordance with the established theory regarding excess BMI as a risk factor for knee OA (Heidari 2011).

A study conducted at the Internal Medicine Outpatient Clinic and Orthopedic \& Traumatology Clinic Dr. Soetomo General Academic Hospital on September 2016 - October 2016 also showed similar results, namely that the majority of knee OA patients had BMI with the obese category (Ahmad et al 2018). The study concluded that Obesity is the strongest modifiable risk factor. During walking, half of the body weight rests on the knee joint. The weight gain will multiply the load on the knee joint when walking. A study in Chingford showed that for every 2 units (approximately $5 \mathrm{~kg}$ body 
weight) increase in Body Mass Index (BMI), the odds ratio for having knee OA radiographically increased by 1.36 points. Likewise, an increased risk of developing progressive knee $\mathrm{OA}$ is seen in overweight individuals (Felson et al 2008).

The highest proportion of menarche age in the case group or osteoarthritis (OA) was in the 12-13 years age range, as many as 21 patients or $53.6 \%$. In the control or non-osteoarthritis (OA) group, the highest proportion of menarche age was in the 12-13-year age range, which was 18 patients or $46.2 \%$ This is not in accordance with the study conducted by the Nord-Trøndelag Health Study (HUNT) and the Norwegian Arthroplasty Register in 2017. This study showed that patients with menarche age $\leq 11$ years had a lower risk factor for developing early knee OA compared to patients with menarche age $\geq 15$ years. This study concludes that the exact cause of menarche and OA have not been known, but there are several responses regarding the effect of menarche age on OA, namely, early menarche age increases the aging process in general, which is known that old age is one of the factors that greatly influences the incidence of OA and the severity of OA and the age of early menarche may be one of the factors causing weight gain while they were young, meanwhile the increase in bodyweight is a significant factor in causing OA (Hellevik et al 2017).

In terms of parity characteristics, it was divided into three groups, namely primiparous ( 1 child), multiparous (1-4 children), grandemultiparous ( $\geq 5$ children). The highest number of case or Osteoarthritis (OA) was in the multiparous group (1-4 children), which was 40 patients or $52.6 \%$, in the control group or nonosteoarthritis $(\mathrm{OA})$ was in the multiparous group with 36 patients or $47,7 \%$. This is not in accordance with a multi-center study conducted by BL Wise et al in 2013. Research conducted by BL Wise et al (2013) showed a significant increase in the risk of osteoarthritis in patients with grandemultiparous parity ( $\geq 5$ children), whereas this study found that the mean result in the case group or Osteoarthritis is multiparous patients who had 2-3 children. A research conducted at the RSUD Dr. Hasan Sadikin Bandung on August - September 2013 also showed that female patients aged $>50$ years with parity $\geq 3$ had a p value $<0.054 .7$, OR 4.7 ; 95\% CI 1.89 11.68 and 4.7 times at risk of developing knee osteoarthritis (Triyadi et al 2015). Research suggests that a high frequency of parity is associated with decreased cartilage volume.

The frequency of parity is associated with an increased risk of patellar cartilage damage, with three or more births having a significant risk of developing cartilage damage (Triyadi et al 2016). In addition, other studies have also concluded that the relationship between parity and osteoarthritis is caused by increasing body weight during pregnancy so that there is also a continuous increase in the load on the joints (Cooley et al 2003).

The characteristics of the use of Hormonal Contraceptives are divided into three groups, namely pills, injections and implants. The highest number for the case group or osteoarthritis (OA) used a lot of pilltype hormonal contraceptive, namely 33 patients or $62.3 \%$, in the control group or non-osteoarthritis (OA) used a lot of hormonal contraceptive with results of 20 patients or $37.7 \%$. The characteristics of the use of hormonal contraceptive pills are divided into two types, namely combination pills and progesterone pills (mini pills).

The highest number for the case group or Osteoarthritis (OA) used a lot of hormonal contraceptives with the type of combination pill, namely 23 patients or $60.5 \%$, in the control group or non-osteoarthritis (OA) mostly using hormonal contraceptive with other types of pills with the results of 22 patients or $71 \%$. This is consistent with a study conducted by the National Health Service (NHS) breast screening centers in England and Scotland in 2009 with a RR 1.02 (95\% CI 0.98 - 1.06) and RR $1.00 \quad(95 \%$ CI 0.96 - 1.04). Oral hormonal contraceptives (pills) did not affect risk factors for knee osteoarthritis in women compared to women who never used oral contraceptives (Liu et al 2009). Meanwhile, the characteristics of the hormonal contraceptive usage duration were divided into 3 groups, namely <1 year, > 1 year, and others.

The usage duration of hormonal contraceptives for the case group or Osteoarthritis (OA), namely > 1 year, 25 patients or $56.8 \%$, in the control group or Nonosteoarthritis (OA) the duration of using hormonal contraceptive was $>1$ year, as many as 19 patients or $43.2 \%$. This is consistent with research conducted by Williams and MacDonald (2021), with results showing that the duration of use of hormonal contraceptives containing estrogen has no significant relationship with the development of osteoarthritis (Williams 2017). Estrogens may have a direct effect on cartilage metabolism, since estrogen receptors are found in chondrocytes and synovium. According to Martel (1999), estrogen may be involved in the regulation of proinflammatory cytokines, such as Interleukin-1, interleukin-6, and tumor necrosis factor, which plays a role in cartilage damage.

\section{CONCLUSION}

The characteristics of the case group were 56-60 years (62.1\%), Body Mass Index 23-24.9 (58.7\%), menarche 
age $12-13$ years $(53.6 \%)$, parity in the multiparous group $(52,6 \%)$, hormonal contraceptive usage in a group with a history of pill usage $(62.3 \%)$ majority used combination pills $(60.5 \%)$ with an average usage duration $>1$ year $(56.8 \%)$. Therefore, there was a relationship between Body Mass Index (BMI) and the type of hormonal contraceptive use against Osteoarthritis (OA) genu in female patients at Universitas Airlangga Hospital Surabaya.

\section{ACKNOWLEDGMENT}

Highest praises to Dr. Sulistiawati, dr., M.Kes. , Patricia Maria Kurniawati, dr., Sp.KFR(K), and RR. Indrayuni Lukitra Wardhani, dr., Sp.KFR as the supervisors in this study; Rehabilitation and Internal Medicine Outpatient Clinic Airlanga University Hospital; to my dearest parents and colleagues; and all participants that had provided huge supports in the conduct of this study.

\section{REFERENCES}

Ahmad IW, Rahmawati LD, Wardhana TH (2018). Demographic profile, clinical and analysis of osteoarthritis patients in Surabaya. Biomolecular and Health Science Journal 1, 34-39.

Anderson AS, Loeser RF (2010). 'Why is Osteoarthritis an Age-Related Disease?'. Best Pract Res Clin Rheumatol 24, 1-18.

Cooley H, Stankovich J, Jones G (2003). The association between hormonal and reproductive factors and hand osteoarthritis. Maturitas 45, 257-65.

Felson DT, Nevitt MC, Yang M, et al (2008). A new approach yields high rates of radiographic progression in knee osteoarthritis. J Rheumatol 35, 2047-54.

Heidari, B (2011). Prevalence, risk factors, pathogenesis and features: Part I. Caspian J Intern Med 2, 205-12.

Hellevik AI, Nordsletten L, Johnsen MB, et al (2017). Age of menarche is associated with knee joint replacement due to primary osteoarthritis (The HUNT Study and the Norwegian Arthroplasty Register). Osteoarthritis Cartilage 25, 2148-2149.

Johnsen MB, Hellevik AI, Småstuen MC, et al (2017). The mediating effect of body mass index on the relationship between smoking and hip or knee replacement due to primary osteoarthritis. A population-based cohort study (the HUNT Study). PLoS One 12, 1-13.
Koentjoro SL (2010). Hubungan antara indeks masa tubuh (imt) dengan derajat osteoartritis lutut menurut kellgren dan lawrence. Journal of bone and mineral metabolism. Available at: http://eprints.undip.ac.id. Accessed January 132020.

Liu B, Balkwill A, Cooper C, et al (2009). Reproductive history, hormonal factors and the occurrence of hip and knee replacement for osteoarthritis in middle-aged women. Ann Rheum Dis 68, 1165-70.

Martel-Pelletier J (1999). Proinflammatory mediators and osteoarthritis. Osteoarthritis Cartilage 7, 315-6.

Ministry of Health (2013). Basic health research, Jakarta, Badan Penelitian dan Pengembangan Kesehatan Kementerian RI.

Salim S (2016). Correlation between estrogen and alkaline phosphatase expression in osteoporotic rat model. Dental Journal 49, 76-80.

Sheikh SI, Khanam (2013). Osteoarthritis in post menopausal women. World Journal of Pharmaceutical Science. Available from:https://www.wjpsonline.com. Accessed December 20, 2019.

Soeryadi A, Gessal J, Sengkey LS (2017). Gambaran faktor risiko penderita osteoartritis lutut di instalasi rehabilitasi medik RSUP Prof. Dr. R. D. Kandou Manado periode Januari Juni 2017. Jurnal E-Clinic (ECL) 5, 267-273.

Triyadi A, Pramudiyo R, Iwan JAR (2015). Association of obesity, parity, and history of knee injury with knee osteoarthritis in female. Althea Medical Journal 2, 492-496.

Triyadi A, Pramudiyo R, Rachman JIA (2016). Association of obesity, parity, and history of knee injury with knee osteoarthritis in female. Althea Medical Journal, 2, 492-496.

Williams, JS., MacDonald, MJ (2021). Influence of hormonal contraceptives on peripheral vascular function and structure in premenopausal females: A review. Integrative Cardiovascular Physiology and Pathophysiology 320(1), H77-H89.

Williams, WV (2017). Hormonal contraception and the development of autoimmunity: A review of the literature. Linacre Q 84, 275-295.

Wise BL, Niu J, Zhang Y, et al (2013). The association of parity with osteoarthritis and knee replacement in the multicenter $\mathrm{O}$ steoarthritis study. Osteoarthr Cartil 21, 1849-54.

Zhang Y, Jordan JM (2010). Epidemiology of osteoarthritis. Clin Geriatr Med 26, 355-3. 